\title{
AKIBAT HUKUM ORANG ASING YANG MENYEWAKAN KEMBALI VILLA SEWAAN DI KABUPATEN BADUNG
}

\author{
Oleh: \\ I Gusti Ngurah Bayu Satriawan \\ I Made Mahartayasa \\ Hukum Bisnis Fakultas Hukum Universitas Udayana
}

\begin{abstract}
Demands for lodging especially villa at Badung Regency being increased. Some foreigner at first time just to holiday seeing villa for business. The foreigners rent a villa and they rent it back with different people. As the goal of writing is to know how foreigners rent it back rented villa and the consequences of the law. The methods used in the writing of scientific papers this is empirical juridical research method, is a method by doing observation or research directly into the field to get accurate truth. Regarding how the foreigners renting back rented villa are they rent villa from local people for long time then they renting back to others people. Consequences of the law in general foreigners is not allowed to renting back rented villa, but it can be allowed when the owner agree and back to content of agreement made.
\end{abstract}

Keywords: Foreigners, rent, villa

\begin{abstract}
Abstrak
Kebutuhan penginapan khususnya villa di Kabupaten Badung terus meningkat. Beberapa orang asing yang awalnya berlibur melihat villa menjadi suatu bisnis. Orang asing menyewa villa lalu disewakan kembali kepada orang lain. Tujuan penulisan ini adalah untuk mengetahui bagaimana orang asing menyewakan kembali villa sewaan dan untuk mengetahui akibat hukum yang ditimbulkan. Metode yang digunakan dalam karya tulis ilmiah ini adalah yuridis empris, yaitu suatu metode dengan melakukan observasi atau penelitian secara langsung ke lapangan guna mendapat kebenaran yang akurat. Mengenai bagaimana orang asing menyewakan villa sewaan adalah mereka menyewa villa dari orang lokal dalam jangka waktu yang lama lalu mereka menyewakan kembali villa tersebut kepada orang lain. Akibat hukumnya adalah secara umum tidak diperbolehkan orang asing menyewakan kembali villa sewaan, tetapi dapat diperbolehkan jika hal tersebut disetujui oleh pemilik dengan kembali lagi pada isi kesepakatan perjanjian yang dibuat.
\end{abstract}

Kata kunci : Orang Asing, sewa, villa 


\section{PENDAHULUAN}

\subsection{Latar Belakang}

Dewasa ini di Bali kegiatan pariwisata meningkat sangat pesat dari tahun ke tahun. Meningkatnya kunjungan wisatawan domestik maupun mancanegara membuat pulau Bali makin padat, khususnya di Kabupaten Badung. Padatnya wisatawan membuat kebutuhan hunian makin tinggi dan hal ini dimanfaatkan untuk kepentingan bisnis. Villa merupakan salah satu hunian tempat tinggal yang sangat digemari oleh wisatawan untuk beristirahat selama berlibur di Bali. Hal ini membuat menjamurnya villa di Bali dari tahun ke tahun khususnya di Kabupaten Badung. Villa-villa di Kabupaten Badung dapat ditemukan di berbagai tempat yang dekat dengan obyek wisata yang sudah terkenal karenanya banyak orang yang membangun villa disebabkan keuntungannya yang besar. Villa-villa ini umumnya disewakan dalam waktu per hari, per minggu, sebulan hingga setahun. Semakin berkembangnya pariwisata, semakin berkembang juga kebutuhan hunian wisatawan. Untuk memenuhi kebutuhan hunian tersebut pelaku usaha membuat villa di berbagai tempat yang dekat dengan objek wisata.

Sewa menyewa diatur dalam buku III KUHPerdata tentang perikatan. Berkenaan dengan buku Ketiga mengenai perikatan, definisi hukum perikatan diatur dalam buku Ketiga KUHPerdata, tetapi definisi ini diberikan oleh ilmu pengetahuan, yaitu: "suatu hubungan hukum dalam lapangan harta kekayaan antara dua orang atau lebih di mana pihak yang satu berhak atas sesuatu dan pihak lain berkewajiban atas sesuatu". ${ }^{1}$ Jadi perikatan adalah hubungan hukum antara dua orang atau lebih dimana pihak yang

\footnotetext{
${ }^{1}$ Purwahid Patrik, 1994, Dasar-Dasar Hukum Perikatan, Mandara Maju, Bandung, h. 2.
} 
satu berhak atas sesuatu dan pihak lainnya berkewajiban atas sesuatu baik berupa barang, jasa dan perbuatan.

Pelaku usaha penyewaan villa di Kabupaten Badung umumnya orang lokal, tetapi juga orang asing yang tujuannya hanya liburan tertarik untuk melakukan bisnis penyewaan villa. Perjanjian sewa menyewa merupakan suatu persetujuan, dengan mana pihak yang satu mengikatkan diri untuk memberikan kenikmatan suatu barang kepada pihak yang lain selama waktu tertentu, dengan pembayaran suatu harga yang disanggupi oleh pihak tersebut terakhir itu. ${ }^{2}$ Orang asing ini awalnya menyewa villa untuk berlibur, tetapi mereka yang melakukan bisnis menyewakan kembali villa yang disewa tersebut dengan harga tentu yang lebih mahal dari yang dia bayarkan kepada pemilik. Keuntungan dari bisnis penyewaan villa tentu banyak yang meminati dikarenakan villa merupakan tempat tinggal yang private dan mudah dikustomisasi sesuai selera pemiliknya. Private disini menjadi daya tarik utama orang asing menyewakan kembali villa sewaan yang disewanya pada pemilik. Dalam perjanjian sewa menyewa, barang yang diserahkan itu tidaklah dimiliki, tetapi hanya untuk dipakai dan dinikmati kegunaannya.

\subsection{Tujuan Penelitian}

Tujuan Penelitian ini adalah untuk mengetahui bagaimana penyewaan kembali villa yang disewa oleh orang asing dan juga untuk mengetahui akibat hukum yang ditimbulkan dari penyewaan kembali villa yang disewa oleh orang asing untuk kepentingan bisnis.

\section{ISI MAKALAH}

\footnotetext{
${ }^{2}$ A.A. Indah Kusuma Dewi Made Suksma Prijandhini Devi Salain, 2016, "Perjanjian Sewa Menyewa Rumah Antara Pihak Menyewakan Dan Pihak Penyewa Di Kota Denpasar", Kertha Semaya, Nomer 04, Volume 04, Juli 2016, http://ojs.unud.ac.id/index.php/kerthasemaya/article/view/21821/14446, diakses pada tanggal 10 Mei 2017, pukul 01.32 WITA, h. 2.
} 


\subsection{Metode Penelitian}

Dalam penulisan ini, penelitian yang digunakan adalah penelitian yuridis empiris. Masalah yang timbul ditinjau dan dikaji berdasarkan kenyataan. Adapun jenis pendeketan hukum yang digunakan adalah pendekatan Perundang-undangan dan fakta.

\subsection{Hasil dan Analisis}

\subsubsection{Penyewaan Kembali Villa Sewaan oleh Orang Asing}

Orang asing yang berlibur ke Bali banyak yang tertarik untuk menyewa villa yang banyak berada di kawasan obyek wisata di Kabupaten Badung. Mereka yang tujuan awalnya adalah berlibur dapat berubah untuk tinggal sementara di Bali dengan menyewa villa untuk jangka waktu yang lama. Perjanjian yang dilakukan untuk menyewa villa ada yang dilakukan dapat dengan perjanjian akta otentik atau akte di bawah tangan. Suatu perjanjian adalah suatu tindakan dengan dimana satu orang atau lebih yang mengikatkan dirinya terhadap satu orang atau lebih. ${ }^{3}$ Menurut Pasal 165 H.I.R akta otentik, yaitu surat yang dibuat dibuat oleh atau dihadapan pejabat yang berwenang atau berkuasa untuk membuatnya, untuk membuat atau mewujudkan bukti yang cukup untuk kedua belah masing-masing pihak beserta ahli warisnya dan sekaligus orang yang mendapatkan hak daripadanya, yaitu mengenai segala hal, yang disebut dalam surat tersebut sebagai pemberihauan saja, akan tetapi yang disebut kemudian itu hanya sekedar apa yang diberitahukan tersebut langsung berhubung dengan pokok dalam isi akta tersebut. Pegawai yang berwenang yang dimaksud dalam hal ini adalah hakim, notaris, jurusita pegawai pencatatan sipil dan sebagainya. ${ }^{4}$

${ }^{3}$ Suharnoko, 2012, Hukum Perjanjian: Teori dan Analisa Kasus, Kencana, Jakarta, h. 119.

4 Ny. Retnowulan Sutanto dan Iskandar Oeripkartawinata, 1989, Hukum Acara Perdata dalam Teori dan Praktek, Mandar Maju, Bandung, h. 58. 
Dalam hal perjanjian dibawah tangan yang mana ditandatangani oleh para pihak yang bersangkutan saja. Perjanjian semacam ini hanya mengikat para pihak yang bersangkutan atau terlibat dalam perjanjian, akan tetapi tidak mempunyai kekuatan yang mengikat bagi pihak ketiga. ${ }^{5}$

Berdasarkan fakta yang ada dilapangan khususnya di Kabupaten Badung orang lokal yang mempunyai tanah secara yuridis yakni hak milik akan membangun sebuah bangunan yang akan di fungsikan sebagai penginapan yaitu villa. Villa yang disewakan umumnya hanya bangunan kosong tanpa furniture, hal inilah yang membuat orang asing tertarik untuk menyewa dalam jangka waktu yang lama. Orang asing umumnya menyewa villa pada orang lokal dalam jangka waktu, minimal satu tahun dan menyewakan kembali villa tersebut kepada orang lain.

\subsubsection{Akibat Hukum Menyewakan Villa Sewaan oleh Orang Asing}

Siapapun yang terlibat dalam suatu perjanjian adalah pihak-pihak dalam perjanjian. Para pihak yang membuat suatu perjanjian itu adalah pihak-pihak yang dimaksud, mereka yang mendapatkan hak-hak daripadanya dan para ahli waris, serta para pihak ketiga.

Jenis Perjanjian6

1. Perjanjian sepihak dan timbal balik

Suatu perjanjian yang dinyatakan oleh salah satu pihak akan tetapi memiliki akibat bagi dua pihak adalah perjanjian sepihak, dimana pihak yang memiliki hak untuk menagih dalam bahasa bisnis dinyatakan pihak

\footnotetext{
${ }^{5}$ Salim HS, 2009, Pengantar Hukum Perdata Tertulis (BW), Sinar Grafika, Jakarta, h. 166.

${ }^{6}$ I Ketut Oka Setiawan, 2016, Hukum Perikatan, Sinar Grafika, Jakarta, h. 49 .
} 
kreditur, dan pihak lain yang memiliki kewajiban dinyatakan sebagai debitur. Perjanjian yang memuat hak kepada salah satu pihak, dimana hak itu sekaligus menjadi kewajiban pada pihak lawannya adalah perjanjian timbal balik.

2. Perjanjian cuma-cuma dan atas beban

Perjanjian yang memberikan keuntungan bagi salah satu pihak saja adalah perjanjian cuma-cuma. Perjanjian yang menyatakan prestasi dari salah satu pihak selalu terdapat tegen prestasi dari pihak yang menjadi lawannya dimana antara kedua prestasi tersebut ada suatu hubungan atas suatu titel tertentu.

3. Perjanjian bernama dan tidak bernama

Perjanjian-perjanjian yang biasa dikenal dengan nama tertentu dan itu mempunyai suatu pengaturan lebih khusus dalam undang-undang disebut dengan perjanjian bernama. Perjanjian-perjanjian yang tidak diberikan nama dan pengaturan secara mengkhusus oleh undanundang disebut sebagai perjanjian tidak bernama.

4. Perjanjian konsensual dan riil

Perjanjian yang dilakukan oleh kedua belah pihak atau lebih dan apabila mereka telah mencapai suatu kesesuaian (persetujuan) berupa kehendak untuk membuat perikatan disebut dengan perjanjian konsensual. Perjanjian yang hanya berlaku setelah terjadinya penyerahan suatu barang disebut dengan perjanjian riil.

5. Perjanjian Obligatoir dan Kebendaan

Perjanjian yang hanya memperhatikan suatu kesepakatan pihak-pihak untuk melakukan penyerahan 
suatu benda yang ditujukan kepada pihak lawannya disebut dengan perjanjian obligatoir. Suatu perjanjian dimana dengan nama seseorang memberikan haknya atas suatu benda kepada pihak lawannya, atau suatu perjanjian yang membebani kewajiban para pihak, untuk diserahkan suatu benda itu kepada pihak lain.

Untuk sahnya suatu persetujuan-persetujuan haruslah memiliki empat syarat sahnya perjanjian yang dinyatakan dan diatur dalam Pasal 1320 Kitab Undang-Undang Hukum Perdata yakni

1. Mereka yang sepakat mengikatkan diri

2. Membuat suatu perikatan dibutukan kecakapan

3. suatu hal tertentu

4. suatu sebab yang halal

Syarat subjektif dapat dilihat pada syarat pertama dan syarat kedua seperti yang disebutkan diatas karena menyangkut persoalan pihak-pihak yang mengadakan perjanjian, sedangkan syarat objektif dapat dilihat pada syarat ketiga dan keempat hal ini menyangkut objek dari suatu peristiwa yang diperjanjikan tersebut. ${ }^{7}$

1. Kesepakatan

Dalam mengadakan suatu perjanjian diperlukan suatu kesepakatan, hal ini memiliki arti bahwa para pihak harus mempunyai kebebasan kehendak, ini berarti para pihak tidak boleh mendapat suatu tekanan yang berakibat adanya kecacatan dalam mewujudkan suatu kehendaknya. ${ }^{8}$

2. Kecakapan

7 Ibid, h. 61

8 Ibid. 
Menurut ketentuan Pasal 1329 KUHPer menjelaskan bahwa "setisp orang adalah cakap untuk membuat perikatan perikatan. Tidak cakap yakni mereka yang ditaruh dibawah pengampuan, orang-orang yang belum dewasa, orang orang perempuan dalam hal hal yang ditentukan oleh undangundang, dan secara umum kepada semua orang dimana dalam undang-undang telah melarang membuat suatu persetujuan persetujuan tertentu. ${ }^{9}$

\section{Hal Tertentu}

Hal tertentu merupakan syarat ketiga dari suatu perjanjian, artinya objek (bepaald onderwerp) tertentu haruslah dimiliki oleh suatu perjanjian yang mana sekurang kurangnya dapat ditentukan. Pasal 1333 KUHPer mengatur tentang objek perjanjian yang isinya "suatu persetujuan harus mempunyai pokok suatu barang yang paling sedikit ditentukan jenisnya". Jumlah barang tidak tentu bukanlah menjadi suatu halangan, asalkan jumlah tersebut kemudian dapat dihitung atau ditentukan.

4. Sebab (causa) yang halal

Hubungan sebab akibat dalam hal ini bukanlah sebab (causa), sehingga ajaran causaliteit disini tidak punya hubungan sama sekali dengan pengertian causa, dan juga bukan merupakan causa yang mendorong masing masing pihak mengadakan perjanjian. ${ }^{10}$

Dalam ketentuan Pasal 1559 Kitab Undang-Undang Hukum Perdata yang menyatakan bahwa "penyewa, jika tidak diizinkan, tidak boleh menyalahgunakan barang yang disewanya

${ }^{10}$ Badrulzaman dan Mariam Darus, 1996, Kitab Undang-Undang Hukum Perdata. Buku III Hukum Perikatan dengan Penjelasan, Alumni, Bandung. h. 100. 
atau melepaskan sewanya kepada orang lain, atas ancaman pembatalan persetujuan sewa dan penggantian biaya, kerugian dan bunga sedangkan pihak yang menyewakan, setelah pembatalan itu, tidak wajib menaati persetujuan ulang sewa itu. Jika yang disewa itu berupa sebuah rumah yang didiami sendiri oleh penyewa, maka dapatlah ia atas tanggung jawab sendiri menyewakan sebagian kepada orang lain jika hak itu tidak dilarang dalam persetujuan."

Asas Konensualisme dalam Kitab Undang-Undang Hukum Perdata pada Pasal 1320 yang mengandung arti "kemauan atau will" para pihak untuk saling berpartisipasi mengikatkan diri. Selain itu, asas konsensualisme menekankan suatu janji lahir pada detik terjadinya konsensus (kesepakatan atau persetujuan antara kedua belah pihak) mengenai hal-hal pokok dari apa yang menjadi objek perjanjian. Apabila perjanjian dibuat dalam bentuk tertulis maka bukti tercapainya konsensus adalah saat ditandatanganinya perjanjian itu oleh pihak-pihak yang bersangkutan. ${ }^{11}$

Dengan demikian, orang asing boleh saja menyewakan kembali villa sewaan tersebut kepada pihak ketiga sepanjang telah mendapat persetujuan tertulis atau tercantum di dalam perjanjian sewa -menyewa antara orang asing dan pemilik villa. Akan tetapi, jika hal tersebut secara tegas dilarang dalam perjanjian dan / atau tidak mendapat persetujuan dari pemilik villa, maka orang asing tersebut tidak boleh menyewakan kembali villa sewaan tersebut. Dan apabila orang asing tetap menyewakan kembali villa sewaan tersebut, perjanjian sewa menyewa antara orang asing dan pemilik villa tersebut akan terancam dapat diputuskan sebelum berakhirnya masa sewa.

11 I Ketut Oka Setiawan, op.cit, h. 46 
Prinsip umum yang menjadi dasar dari boleh atau tidaknya orang asing menyewakan kembali rumah sewaan tersebut sebenarnya kembali pada prinsip konsensualitas (kesepakatan). Dalam Pasal 1321 KUHPerdata dijelaskan bahwa "Tiada suatu persetujuan pun mempunyai kekuatan jika diberikan karena kekhilafan atau diperoleh dengan paksaan atau penipuan." Jadi Sepanjang disepakati bersama dan memenuhi syarat-syarat sahnya perjanjian, tanpa adanya paksaan, penipuan maupun kekhilafan, maka orang asing dapat menyewakan kembali villa tersebut.

Ketentuan yang lebih spesifik dapat penulis lihat pada ketentuan PP No. 44 Tahun 1994 tentang Penghunian Rumah Bukan Oleh Pemilik yang memang hal yang diatur adalah rumah, tetapi penulis mengansumsikan bahwa villa merupakan tempat tinggal yang hampir mirip dengan rumah pada umumnya walaupun tujuan utamanya adalah untuk komersial dan memperoleh keuntungan.

Dalam PP No. 44 Tahun 1994 tentang Penghunian Rumah Bukan Oleh Pemilik Pasal 9 ayat (1) menentukan bahwa penyewa dengan cara apapun dilarang menyewakan kembali dan atau memindahkan hak penghunian atas rumah yang disewanya kepada pihak ketiga tanpa izin tertulis dari pemilik. Dan apabila orang asing menyewakan kembali villa tersebut tanpa persetujuan tertulis dari pemilik villa tersebut, maka dalam hubungan sewa menyewa dapat diputuskan sebelum berakhirnya jangka waktu sewa -menyewa dan si penyewa berkewajiban mengembalikan villa tersebut dengan baik seperti keadaan semula dan tidak dapat meminta kembali uang sewa yang sudah dibayarkan, hal ini tertuang dalam Pasal 11 ayat (1) huruf b PP No. 44 Tahun 1994. 


\section{PENUTUP}

\subsection{Kesimpulan}

Bali merupakan pulau yang terkenal akan keindahan alam dan budayanya, menjadi daya tarik utama wisatawan. Keindahan alam dan budaya yang kental membuat meningkatnya kunjungan wisatawan domestik maupun mancanegara. Hal ini tentu juga mempengaruhi kebutuhan tingkat jumlah penginapan tempat tinggal untuk para wisatawan yang berkunjung ke Bali. Banyak orang yang melihat ini sebagai bisnis untuk membuat suatu penginapan tempat tinggal. Penginapan tempat tinggal yang paling digemari adalah villa. Villa merupakan penginapan tempat tinggal yang private sehingga digemari oleh wisatawan. Orang asing yang mulanya hanya bertujuan untuk berwisata, melihat ini sebagai bisnis yang menguntungkan. Sehingga mereka menyewa villa dalam waktu yang lama dan disewakan kembali untuk wisatawan lainnya yang berkunjung ke Bali.

Akibat hukum yang ditimbulkan oleh penyewaan kembali villa oleh orang asing untuk kepentingan bisnis sebenarnya tidak diperbolehkan menurut PP No. 44 Tahun 1994 tentang Penghunian Rumah Bukan Oleh Pemilik Pasal 9 ayat (1) yang melarang penyewaan kembali rumah yang disewa, tetapi jika dalam perjanjian yang dibuat dan disepakti disetujui oleh pemilik maka orang asing dapat menyewakan kembali villa yang disewanya tersebut disewakan kembali kepada orang lain. Karena hal ini kembali lagi pada sahnya suatu perjanjian dan asas konsensualisme yang diatur dalam Pasal 1320 Kitab UndangUndang Hukum Perdata. 


\section{DAFTAR PUSTAKA}

\section{BUKU}

Badrulzaman, Mariam Darus, 1996, Kitab Undang-Undang Hukum Perdata Buku III Hukum Perikatan dengan Penjelasan, Alumni, Bandung.

Patrik, Purwadi, 1994, Dasar-Dasar Hukum Perikatan, Mandara Maju, Bandung.

Salim, HS, 2009, Pengantar Hukum Perdata Tertulis (BW), Sinar Grafika, Jakarta.

Setiawan, I Ketut Oka, 2016, Hukum Perikatan, Sinar Grafika, Jakarta.

Suharnoko, 2012, Hukum Perjanjian: Teori dan Analisa Kasus, Kencana, Jakarta.

Sutanto, Ny. Retnowulan, Iskandar Oeripkartawinata, 1989, Hukum Acara Perdata dalam Teori dan Praktek, Mandar Maju, Bandung.

\section{JOURNAL}

Kusuma, A.A. Indah, Dewi Made Suksma Prijandhini Devi Salain, 2016, "Perjanjian Sewa Menyewa Rumah Antara Pihak Menyewakan Dan Pihak Penyewa Di Kota Denpasar", Kertha Semaya, Nomer 04, Volume 04, Juli 2016, URL : http://ojs.unud.ac.id/index.php/kerthasemaya/article/view/ $\underline{21821 / 14446 .}$

\section{PERUNDANG-UNDANGAN}

Kitab Undang-Undang Hukum Perdata

PP No. 44 Tahun 1994 Tentang Penghunian Rumah Bukan Oleh Pemilik 